\title{
Dysfunction of CD27+IgD+B cells correlates with aggravated systemic lupus erythematosus
}

\author{
wei zhang ${ }^{1}$, Yongfu Wang ${ }^{2}$, Fanlei $\mathrm{Hu}^{3}$, fuai $\mathrm{lu}^{2}$, Tao $\mathrm{Wu}^{2}$, and ${\mathrm{Ke} \mathrm{Li}^{4}}^{4}$ \\ 1 The Second Affiliated Hospital, School of Medicine, Xi'an Jiaotong University \\ ${ }^{2}$ First Affiliated Hospital of Baotou Medical College \\ ${ }^{3}$ Peking University People's Hospital \\ ${ }^{4}$ The Second Affiliated Hospital of Xi'an Jiaotong University
}

September 11, 2020

\begin{abstract}
Apoptotic signaling pathway is obviously disordered in systemic lupus erythematosus (SLE). The contemporaneous occurrence of enhanced apoptosis and impaired phagocytosis lead to the cumulative exposure to autoantigens, resulting in autoantibody production and autoimmunity. Natural IgM (nIgM) plays a key role in the clearance of apoptotic cells and prevents them from inducing abnormal autoimmunity. B-1 cells and innate-like B cells (ILBs) are proved to be the major producer of natural IgM. Human CD27+IgD+B cells, also termed as un-switched memory B cells, are recently proposed to be a kind of ILBs. However, functional features and characteristics of these cells in SLE remain poorly understood.In this study, we find that in SLE patients the frequencies of $\mathrm{CD} 27+\operatorname{IgD}+\mathrm{B}$ cells are significantly decreased. Moreover, these cells are functionally impaired in producing natural antibody-like IgM. These $\mathrm{CD} 27+\operatorname{IgD}+\mathrm{B}$ cells are negatively correlated with SLE patient clinical and immunological features. After effective therapy with disease remission in SLE, the frequencies of these cells could be recovered. Taken together, our results suggest that the dysfunction of $\mathrm{CD} 27+\operatorname{Ig} D+\mathrm{B}$ cells potentially contribute to the exacerbation of SLE, and modulating the features of these cells might provide therapeutic target for this persistent disease.
\end{abstract}

\section{Dysfunction of $\mathrm{CD}^{+}{ }^{+} \mathrm{IgD}^{+} \mathrm{B}$ cells correlates with aggravated systemic lupus erythematosus}

Zhang, $W^{1,2} ;$ Wang, $\mathrm{YF}^{2} ; \mathrm{Hu}, \mathrm{Fl}^{3,4} ; \mathrm{Lu}, \mathrm{FA}{ }^{2} ; \mathrm{Wu}, \mathrm{T}^{2} ; \mathrm{Li}, \mathrm{K}^{1^{*}}$

1. Core Research Laboratory, T he Second Affiliated Hospital, School of Medicine, Xi'an Jiaotong University, Xi'an, China

2.

Department of Rheumatology, The first affiliated hospital of Baotou Medical College, Institut of Immunology and Rheumatology, Baotou Medical College,(Inner Mongolia Key Laboratory of Autoimmunity, 014010 Baotou, China)

3. Department of Rheumatology and Immunology, Peking University People's Hospital 83 Beijing Key Laboratory for Rheumatism Mechanism and Immune Diagnosis (BZ0135), Beijing, China.

4. State Key Laboratory of Natural and Biomimetic Drugs, School of Pharmaceutical Sciences, Peking University, Beijing, China

Corresponding author,s e-mail, ke.li@mail.xjtu.edu.cn

\section{Summary}


Apoptotic signaling pathway is obviously disordered in systemic lupus erythematosus (SLE). The contemporaneous occurrence of enhanced apoptosis and impaired phagocytosis lead to the cumulative exposure to autoantigens, resulting in autoantibody production and autoimmunity. Natural IgM (nIgM) plays a key role in the clearance of apoptotic cells and prevents them from inducing abnormal autoimmunity. B-1 cells and innate-like B cells (ILBs) are proved to be the major producer of natural IgM. Human $\mathrm{CD27}^{+} \mathrm{IgD}^{+} \mathrm{B}$ cells, also termed as unswitched memory B cells, are recently proposed to be a kind of ILBs. However, functional features and characteristics of these cells in SLE remain poorly understood.In this study, we find that in SLE patients the frequencies of $\mathrm{CD}^{+} 7^{+} \mathrm{IgD}^{+} \mathrm{B}$ cells are significantly decreased. Moreover, these cells are functionally impaired in producing natural antibody-like IgM. These $\mathrm{CD}^{2}{ }^{+} \mathrm{IgD}^{+} \mathrm{B}$ cells are negatively correlated with SLE patient clinical and immunological features. After effective therapy with disease remission in SLE, the frequencies of these cells could be recovered. Taken together, our results suggest that the dysfunction of $\mathrm{CD}^{2} 7^{+} \mathrm{IgD}^{+} \mathrm{B}$ cells potentially contribute to the exacerbation of SLE, and modulating the features of these cells might provide therapeutic target for this persistent disease.

Keywords: systemic lupus erythematosus, innate-like B cells, $\mathrm{CD} 27^{+} \mathrm{IgD}^{+} \mathrm{B}$ cells, natural IgM

\section{Introduction}

Systemic lupus erythematosus (SLE) is a prototypic systemic autoimmune disease that develops in genetically susceptible individuals in response to environmental factors(1). The pathogenesis remains to be fully elucidated. Autoantibodies are key mediators in determining the clinical manifestations of SLE. The mechanisms by which antibodies may be harmful to self-tissues encompassed complement mediated inflammation, cell apoptosis and immune-complexes mediated damage. However, the precise cooperation of antibodies in SLE have not been unraveled so far(2).

Apoptosis is an energy-dependent process that leads to the programmed destruction of cells. It is tightly regulated by the expression of cell surface molecules such as Fas and intracellular protooncogenes including Bcl-2 and the Bax family members(3). It has been proved that apoptotic signaling pathway is obviously disordered in SLE patients. Abnormal expression of a large number of apoptotic signaling molecules such as TNF-related apoptosis inducing ligand (TRAIL), TNF-like weak inducer of apoptosis (TWEAK) and death ligand FasL (Fas ligand) leads to abnormal increase of apoptotic cells $(4,5)$. In addition, the body of SLE patients also has obstacles to the removal of apoptotic cells. Cell death, including apoptosis, necrosis and NETosis (special cell death of neutrophil through NETs), is the major potential resource of self-dsDNA which activates the immune system and leads finally to autoimmune disease(6).

Natural immunity is responsible for identification and elimination of damaged and apoptotic cells. Meanwhile, it also complete the intricate regulation of inflammatory response and enhance immune tolerance. Natural $\operatorname{IgM}(\mathrm{nIgM})$ is an important component of the body's innate immune system. nIgM is an evolutionarily conserved molecule and reacts with a variety of epitopes expressed on both self-and non-self antigens (7). $n I g M$ deficiency is associated with an increased tendency toward the development of autoimmune disease. It plays a key role in the clearance of apoptotic cells and prevents apoptotic cells from inducing abnormal autoimmunity.

B-1 cells and innate-like B cells (ILBs) are proved to be the major producer of natural IgM. Early transfer experiments showed that more than $80 \%$ of serum natural IgM is derived from B1 cells(8). ILBs are heterogeneous populations of unconventional $\mathrm{B}$ cells with innate sensing and responding properties. In mice, ILBs are composed of B1 cells, marginal zone (MZ) B cells and other related B cells. CD19 ${ }^{+} \mathrm{CD} 27^{+} \operatorname{IgD}{ }^{+} \mathrm{B}$ cells which are also termed as un-switched memory B cells have been proposed to be a kind of human $\operatorname{ILBs}(9)$. ILBs maintain natural IgM levels at steady state, and they can rapidly acquire immune regulatory activities through the secretion of natural IgM and IL-10 after innate activation(10). Our previous study indicated that $\mathrm{CD} 27^{+} \mathrm{IgD}^{+} \mathrm{B}$ cells were impaired in rheumatoid arthritis (RA) with dysfunctional features, which might contribute to the disease perpetuation(11). Nevertheless, the characteristics of $\mathrm{CD}_{2} 7^{+} \operatorname{IgD}{ }^{+} \mathrm{B}$ 
cells and their potential role in SLE are largely unknown.

In this study, we determined the frequencies and natural antibody-like IgM-producing capacity of $\mathrm{CD} 27^{+} \mathrm{IgD}{ }^{+} \mathrm{B}$ cells in SLE patients. In addition, we also analyzed their clinical associations and revealed their tendency after therapy.

\section{Materials and Methods}

\section{Patients and specimens}

50 SLE patients and 50 healthy controls (HC) were enrolled in the study. SLE patients were recruited from the First Affiliated Hospital of Baotou Medical College who fulfilled the American College of Rheumatology criteria for the classification of SLE(12). The main characteristics of SLE patients are listed in Table 1. Disease activity was measured by the modified Systemic Lupus Erythematosus Disease Activity Index (SLEDAI-2K) (13), and was divided into low-disease activity (LDA) (SLEDAI 0-4, $\mathrm{n}=34$ ) and active disease ( $\mathrm{SLEDAI}>4, \mathrm{n}=16$ ). This study was approved by Institutional Medical Ethics Review Board of Baotou Medical College, and all the participants provided written informed consent.

Twelve SLE patients were follow-up study. All patients had received immunosuppressant and achieved remission. Blood samples were obtained before the initiation of treatment and after 4 weeks of treatment. The characteristics of the patients before and after treatment are shown in Table 2

\section{Flow cytometry analysis}

For $\mathrm{CD} 27^{+} \mathrm{IgD}^{+} \mathrm{B}$ cell detection, $2 \mathrm{ml}$ blood was collected from SLE patients and healthy controls, and $100 \mu \mathrm{l}$ fresh whole blood cells was extracted and stained with the following antibodies:APC-CY7-conjugated antiCD19 (Biolegend, San Diego, CA, USA), APC-conjugated anti-CD27 (eBioscience, San Diego, CA, USA), and FITC-conjugated anti-IgD (eBioscience). Then the red blood cells were lysed using the RBC lysis buffer (MultiSciences, Hangzhou, China) and the left cells were analyzed on FACS Aria II. Dead cell exclusion was performed by scatter profiles and 7-AAD staining during all the flow cytometric analyses.

\section{Cell sorting and Culture}

Fluorescence-activated cell sorting (FACS) were used to purify $\mathrm{CD} 27^{+} \mathrm{IgD}{ }^{+} \mathrm{B}$ cells, $10 \mathrm{ml}$ blood was collected from SLE patients and healthy controls, peripheral blood mononuclear cells (PBMCs) were isolated from fresh blood samples using Ficoll density-gradient centrifugation, and then were stained as described above. After that, the aimed cells were harvested into the collection solution (RPMI 1640 supplemented with 10\% FBS and $2 \%$ antibiotics) using FACS Aria II flow cytometry sorter according to the manufacturer's instructions. The purified cells were further analyzed after sorting, the purity of which was $95-99 \%$.

\section{Quantitative real-time RT-PCR analysis}

Total RNA was extracted from $\mathrm{CD} 27^{+} \mathrm{IgD}^{+} \mathrm{B}$ cells using RNeasy Mini Kit (Qiagen, Hilden, Germany), and reverse transcribed into cDNA with the RevertAid First Strand cDNA synthesis kit (Fermentas, Glen Burnie, MD, USA) according to the manufacturer's instructions. The resulting cDNA was subjected to real-time PCR analyses. Gene expression was quantified relative to the expression of the housekeeping gene GAPDH as well as $\beta$-actin, and was normalized to control by standard $2^{-\Delta \Delta^{*} \mathrm{~T}}$ calculation(11).

\section{ELISPOT analysis}

ELISPOT was performed using the ELISpotPLUS Human IgM Kit (MABTECH AB, Sweden). Briefly, 1 $\times 10^{4}$ flow cytometry-sorted $\mathrm{CD} 27^{+} \mathrm{IgD}^{+} \mathrm{B}$ cells as well as other $\mathrm{B}$ cell subsets from healthy individuals or SLE patients were subjected to IgM detection in the presence of anti-CD40 (3 $\mu \mathrm{g} / \mathrm{ml}$, eBioscience) and CpG $(10 \mu \mathrm{g} / \mathrm{ml}$, Invivogen, San Diego, CA, USA $)$ for $24 \mathrm{~h}$. The results were analyzed on an ImmunoSpot Analyzer (Cellular Technology Ltd., Shaker Heights, OH, USA)

\section{Statistics analysis}


All statistical calculations were performed using the statistical software program SPSS 17.0 (SPSS, Chicago, IL, USA). Differences between various groups were evaluated by the Student's t-test, paired t-test, one-way ANOVA test, or spearman test, and were statistically significant at $\mathrm{P}<0.05$.ResultsThe frequencies ofCD27 ${ }^{+} \mathrm{IgD}^{+} \mathrm{B}$ cells are significantly decreased in SLE patients

$\mathrm{B}$ cells could be divided into four subsets based on their expression of CD27 and IgD, including naïve B cells $\left(\mathrm{CD} 27^{-} \operatorname{IgD}{ }^{+}\right)$, Innate-like B cells $\left(\mathrm{CD} 27^{+} \mathrm{IgD}^{+}\right)$, switched memory B cells $\left(\mathrm{CD}^{2} 7^{+} \operatorname{IgD}^{-}\right)$, and double negative B cells $\left(\mathrm{CD} 27^{-} \mathrm{IgD}^{-}\right)$as demonstrated in Figure $1 \mathrm{~A}$. To reveal the role of $\mathrm{CD} 27^{+} \operatorname{IgD}{ }^{+} \mathrm{B}$ cells in SLE pathogenesis, we first compared their frequencies between SLE patients and healthy individuals. As shown in Figure $1 \mathrm{~B}$ and $\mathrm{C}$, compared to the 50 healthy volunteers, the frequencies of $\mathrm{CD} 27^{+} \operatorname{IgD}{ }^{+} \mathrm{B}$ cells were significantly decreased in the peripheral blood of 50 SLE patients.

\section{$\mathrm{CD27}^{+} \mathrm{IgD}^{+} \mathrm{B}$ cells correlate with SLE patient clinical and immunological features}

The associations of the $\mathrm{CD}_{2} 7^{+} \mathrm{IgD}^{+} \mathrm{B}$ cell frequencies with demographic and clinical characteristics were analyzed. As shown in Figures 2A-L and Table 3, WBC, Platelet count and serum C3 level positively correlated with $\mathrm{CD} 27^{+} \mathrm{IgD}+\mathrm{B}$ cells. We also found the frequencies of these $\mathrm{CD} 27^{+} \mathrm{IgD}^{+} \mathrm{B}$ cells were negatively correlated with Serum Creatinine level, SLEDAI and Anti-dsDNA. However, no correlations were noted between the disease duration, ESR, serum C4 level and serum IgA, IgG, IgM level with $\mathrm{CD} 27^{+} \operatorname{IgD}{ }^{+} \mathrm{B}$ cells. These data demonstrated that $\mathrm{CD} 27^{+} \mathrm{IgD}^{+} \mathrm{B}$ cells were numerically deficient under SLE circumstance.

\section{$\mathrm{CD}^{2}{ }^{+} \mathrm{IgD}^{+} \mathrm{B}$ cells Demonstrate Dampened IgM-Producing competency in SLE}

To determine the functional changes of $\mathrm{CD} 27^{+} \operatorname{IgD}{ }^{+} \mathrm{B}$ cells, we then examined the production of $\operatorname{IgM}$ by $\mathrm{CD} 27^{+} \mathrm{IgD}{ }^{+} \mathrm{B}$ cells in SLE patients. $\mathrm{CD} 27^{+} \mathrm{IgD}^{+} \mathrm{B}$ cells from active SLE patients (SLEDAI $>5$ ) and healthy individuals were isolated by flow cytometry sorting and subjected to ELISPOT and QPCR analyses. ELISPOT analysis showed that under SLE circumstance, the IgM-producing capacities of these cells were dampened (Figure 3A). QPCR analyses further confirmed that the IgM transcripts of these $\mathrm{CD} 27^{+} \mathrm{IgD}{ }^{+} \mathrm{B}$ cells were significantly decreased in SLE (Figure 3B). Taken together, these results indicated that $\mathrm{CD} 27^{+} \mathrm{IgD}^{+} \mathrm{B}$ cells were functionally impaired in producing IgM in SLE.

\section{$\mathrm{CD}^{+}{ }^{+} \mathrm{IgD}^{+} \mathrm{B}$ cells are recovered in SLE patients with disease remission after therapy}

To ascertain the usefulness of $\mathrm{CD} 27^{+} \mathrm{IgD}^{+} \mathrm{B}$ cells as a biomarker for disease activity, we further evaluated whether these cells would be recovered after effective therapy. 12 patients who were diagnosed as SLE were studied when they were in relapse and 4 weeks after the initiation of treatments. As shown in Table 2, after treatments reduced significantly disease activity as measured by SLEDAI. The anti-dsDNA and $24 \mathrm{~h}$ urinary protein were decreased with the serum C3 and C4 normalized to some extent. The total number of leukocyte and platelet were increased after the treatments.

The frequency of $\mathrm{CD} 27^{+} \mathrm{IgD}{ }^{+} \mathrm{B}$ cells were examined before and after 4 weeks of initiation of treatments are shown in Figure 4A. As measured by SLEDAI, all patients showed a significant reduction in disease activity after treatment (Figure 4B) and the frequency of $\mathrm{CD} 27^{+} \mathrm{IgD}{ }^{+} \mathrm{B}$ cells was significantly increased (Figure $4 \mathrm{C}$ ). All these results suggested that the impaired $\mathrm{CD} 27^{+} \operatorname{IgD}{ }^{+} \mathrm{B}$ cells in SLE patients could be recovered after effective therapy, indicating their deficiency might be correlated with the development of SLE.

\section{Discussion}

In this study, we observed that the rate of $\mathrm{CD} 27^{+} \operatorname{IgD}{ }^{+} \mathrm{B}$ cells were decreased and functionally impaired in producing natural antibody-like IgM in patients with SLE when compared with healthy controls. The number of $\mathrm{CD} 27^{+} \mathrm{IgD}{ }^{+} \mathrm{B}$ cells is correlated with the clinical characteristics of SLE patients. After effective therapy, these $\mathrm{CD} 27^{+} \mathrm{IgD}^{+} \mathrm{B}$ cells could get recovered.

In SLE, the number of apoptotic cells increases while the phagocytosis function is impaired $(14,15)$. The contemporaneous occurrence of enhanced apoptosis and impaired phagocytosis is considered to be a key process in the pathogenesis of SLE and can lead to the cumulative exposure to the autoantigens which resulted in autoantibody production and autoimmunity(16). Apoptotic cells are normally phagocytosed 
by professional phagocytes such as macrophages, but the clearance of apoptotic cells depends not only on functioning phagocytes but also on soluble proteins that act as opsonins and/or bridging molecules. Phagocytosis of apoptotic cells can be enhanced by C-reactive protein (CRP), serum amyloid $\mathrm{P}$ component (SAP), C1q, IgM, MBL and other proteins, forming a redundant backup mechanism. Previous studies have found that phagocytic activity of macrophages is reduced three-fold to four-fold in the absence of IgM (17). Decreased natural IgM level in SLE patients may lead to inefficient clearance of apoptotic cells, leading to the accumulation of dead cells in peripheral blood(18). SLE patients were reported to demonstrate lower levels of anti-PC natural IgM, reductions of which correlated with duration of the disease. Lower levels of anti-PC natural IgM were also reported to be associated with more frequent cardiovascular events in patients with SLE (19). However, till now little is known about the causes of natural IgM defects in SLE patients.

In our previous study, we proved that $\mathrm{CD} 27^{+} \mathrm{IgD}{ }^{+} \mathrm{B}$ cells can spontaneously secrete

IgM that were polyreactive and low affinitive. We termed these $\mathrm{CD} 27^{+} \operatorname{IgD}{ }^{+} \mathrm{B}$ cells-derived $\operatorname{IgM}$ as natural antibody-like IgM. In this study, we found that $\mathrm{CD} 27^{+} \mathrm{IgD}^{+} \mathrm{B}$ cells in SLE patients were significantly reduced and negatively correlated with SLEDAI and anti-dsDNA autoantibodies. These data are consistent with previous reports $(20,21)$ and, taken together, indicate that the B cell-subsets are disordered in SLE patients. Since different B cell subsets have different functional characteristics, the imbalance of their proportions will lead to the imbalance of immune homeostasis and promote the development of the disease to some extent. Cytokines such as IFN-gamma, BAFF, TNF-alpha, il-6, il-21 in the serum of SLE patients will affect the B cell signaling pathway and thus increase its activation and differentiation(22-24). Therefore, we speculated that the inflammatory environment in SLE patients is one of the reasons for the reduction of $\mathrm{CD} 27^{+} \operatorname{IgD}{ }^{+} \mathrm{B}$ cells, but this speculation need to be further studied.

In addition, QPCR and ELISPOT analyses showed that the ability of $\mathrm{CD} 27^{+} \operatorname{IgD}{ }^{+} \mathrm{B}$ cells to secrete $\operatorname{IgM}$ in SLE patients was significantly lower than that in healthy control, indicating that in SLE patients, $\mathrm{CD} 27^{+} \mathrm{IgD}{ }^{+} \mathrm{B}$ cells has defects not only in quantity, but also in function. Therefore, this is also a reason for the accumulation of apoptotic cells and the generation of autoimmunity in SLE patients. The decreased TCR or BCR diversity has been observed in cancers and autoimmune diseases, which may contribute to the development of the diseases $(25)$. Our previous research has shown that the $\mathrm{BCR}$ repertoire of $\mathrm{CD} 27^{+} \operatorname{IgD}{ }^{+} \mathrm{B}$ cells was altered in RA. Compared with healthy controls, the variable region of the $\mathrm{CD}_{2} 7^{+} \mathrm{IgD}{ }^{+} \mathrm{B}$ cellsderived IgM $\mu$ chain showed much narrower spectrum. Therefore, we speculated that the BCR repertoire of $\mathrm{CD} 27^{+} \operatorname{IgD}{ }^{+} \mathrm{B}$ cells was also changed in SLE, and the following study will be conducted to score the BCR repertoire of $\mathrm{CD}_{2} 7^{+} \mathrm{IgD}{ }^{+} \mathrm{B}$ cells in SLE patients.

In summary, we demonstrated that $\mathrm{CD} 27^{+} \mathrm{IgD}^{+} \mathrm{B}$ cells were numerically and functionally impaired in SLE. $\mathrm{CD} 27^{+} \mathrm{IgD}{ }^{+} \mathrm{B}$ cells are a reliable biomarker for active SLE and that the role of these cells in the pathogenesis of SLE deserve to further investigation.

\section{Acknowledgements}

This work was supported by the National Nature Science Foundation of China (81860295), the Inner Mongolia Autonomous Region Science and Technology Plan Project (201802089, 2019GG052), the Nature Science Foundation of Inner Mongolia(2017MS0809).

\section{Disclosures}

The authors have no financial conflict of interest.

\section{Author's contributions}

Conceived and designed the experiments: W. Z., Y. W., K.L.; Performed the experiments: W. Z., T.W.; Analyzed the data: W. Z., Y. W., F. H.; Contributed reagents, materials and analysis tools: L.F., F. H., Y. W.; Wrote the manuscript: W. Z.; Reviewed and edited the manuscript: F. H., K.L.

\section{References}


1. Sawada T, Fujimori D, Yamamoto Y. Systemic lupus erythematosus and immunodeficiency. Immunological medicine. 2019:1-9.

2. Gatto M, Iaccarino L, Ghirardello A, Punzi L, Doria A. Clinical and pathologic considerations of the qualitative and quantitative aspects of lupus nephritogenic autoantibodies: A comprehensive review. J Autoimmun. 2016;69:1-11.

3. Oltvai ZN, Milliman CL, Korsmeyer SJ. Bcl-2 heterodimerizes in vivo with a conserved homolog, Bax, that accelerates programmed cell death. Cell. 1993;74(4):609-19.

4. Salem MN, Taha HA, Abd El-Fattah El-Feqi M, Eesa NN, Mohamed RA. Urinary TNF-like weak inducer of apoptosis (TWEAK) as a biomarker of lupus nephritis. Z Rheumatol. 2018;77(1):71-7.

5. Choe JY, Kim SK. Serum TWEAK as a biomarker for disease activity of systemic lupus erythematosus. Inflamm Res. 2016;65(6):479-88.

6. Mahajan A, Herrmann M, Munoz LE. Clearance Deficiency and Cell Death Pathways: A Model for the Pathogenesis of SLE. Front Immunol. 2016;7:35.

7. Nguyen TT, Baumgarth N. Natural IgM and the Development of B Cell-Mediated Autoimmune Diseases. Crit Rev Immunol. 2016;36(2):163-77.

8. Baumgarth N, Herman OC, Jager GC, Brown L, Herzenberg LA, Herzenberg LA. Innate and acquired humoral immunities to influenza virus are mediated by distinct arms of the immune system. Proceedings of the National Academy of Sciences of the United States of America. 1999;96(5):2250-5.

9. Weller S, Braun MC, Tan BK, Rosenwald A, Cordier C, Conley ME, et al. Human blood IgM "memory" B cells are circulating splenic marginal zone B cells harboring a prediversified immunoglobulin repertoire. Blood. 2004;104(12):3647-54.

10. Zhang X. Regulatory functions of innate-like B cells. Cell Mol Immunol. 2013;10(2):113-21.

11. Hu F, Zhang W, Shi L, Liu X, Jia Y, Xu L, et al. Impaired CD27(+) $\operatorname{IgD}(+)$ B Cells With Altered Gene Signature in Rheumatoid Arthritis. Front Immunol. 2018;9:626.

12. Hochberg MC. Updating the American College of Rheumatology revised criteria for the classification of systemic lupus erythematosus. Arthritis Rheum. 1997;40(9):1725.

13. Gladman DD, Ibanez D, Urowitz MB. Systemic lupus erythematosus disease activity index 2000. J Rheumatol. 2002;29(2):288-91.

14. Mistry P, Kaplan MJ. Cell death in the pathogenesis of systemic lupus erythematosus and lupus nephritis. Clin Immunol. 2017;185:59-73.

15. Biermann MH, Veissi S, Maueroder C, Chaurio R, Berens C, Herrmann M, et al. The role of dead cell clearance in the etiology and pathogenesis of systemic lupus erythematosus: dendritic cells as potential targets. Expert Rev Clin Immunol. 2014;10(9):1151-64.

16. Munoz LE, van Bavel C, Franz S, Berden J, Herrmann M, van der Vlag J. Apoptosis in the pathogenesis of systemic lupus erythematosus. Lupus. 2008;17(5):371-5.

17. Quartier P, Potter PK, Ehrenstein MR, Walport MJ, Botto M. Predominant role of IgM-dependent activation of the classical pathway in the clearance of dying cells by murine bone marrow-derived macrophages in vitro. Eur J Immunol. 2005;35(1):252-60.

18. Munoz LE, Janko C, Schulze C, Schorn C, Sarter K, Schett G, et al. Autoimmunity and chronic inflammation - two clearance-related steps in the etiopathogenesis of SLE. Autoimmun Rev. 2010;10(1):3842. 
19. Gronwall C, Akhter E, Oh C, Burlingame RW, Petri M, Silverman GJ. IgM autoantibodies to distinct apoptosis-associated antigens correlate with protection from cardiovascular events and renal disease in patients with SLE. Clin Immunol. 2012;142(3):390-8.

20. Wei C, Anolik J, Cappione A, Zheng B, Pugh-Bernard A, Brooks J, et al. A new population of cells lacking expression of CD27 represents a notable component of the B cell memory compartment in systemic lupus erythematosus. J Immunol. 2007;178(10):6624-33.

21. Rodriguez-Bayona B, Ramos-Amaya A, Perez-Venegas JJ, Rodriguez C, Brieva JA. Decreased frequency and activated phenotype of blood CD27 IgD IgM B lymphocytes is a permanent abnormality in systemic lupus erythematosus patients. Arthritis Res Ther. 2010;12(3):R108.

22. Chang NH, Li TT, Kim JJ, Landolt-Marticorena C, Fortin PR, Gladman DD, et al. Interferon-alpha induces altered transitional B cell signaling and function in Systemic Lupus Erythematosus. J Autoimmun. $2015 ; 58: 100-10$.

23. Schweighoffer E, Vanes L, Nys J, Cantrell D, McCleary S, Smithers N, et al. The BAFF receptor transduces survival signals by co-opting the B cell receptor signaling pathway. Immunity. 2013;38(3):475-88.

24. Sweet RA, Lee SK, Vinuesa CG. Developing connections amongst key cytokines and dysregulated germinal centers in autoimmunity. Curr Opin Immunol. 2012;24(6):658-64.

25. Sowell RT, Kaech SM. Probing the Diversity of T Cell Dysfunction in Cancer. Cell. 2016;166(6):1362-4.

Table 1 Clinical characteristics of SLE patients

\begin{tabular}{ll}
\hline Characteristics & SLE $(\mathrm{N}=50)$ \\
\hline Age, mean(range), years & $45.6(17-67)$ \\
Female/male & $46 / 4$ \\
Duration of diagnosis, mean(range), years & $6.8(1-30)$ \\
SLEDAI score, mean(range) & $3.8(0-12)$ \\
Anti-dsDNA, IU/mL, mean(range) & $244.5(100-659)$ \\
IgG, g/L, mean(range) & $14.35(7.4-29.2)$ \\
Serum C3, g/L, mean(range) & $0.94(0.26-1.51)$ \\
Serum C4, g/L, mean(range) & $0.19(0.03-0.40)$ \\
Serum Creatinine, $\mu$ mol/L, mean(range) & $87.99(56-189)$ \\
WBC, 109/L (mean \pm SD) & $3.75 \pm 1.04$ \\
Platelet, 1012/L (mean \pm SD) & $171.76 \pm 70.76$ \\
Urinary proteins, g/24h, mean(range) & $0.4(0-3.4)$ \\
\hline
\end{tabular}

Note: SLE, systemic lupus erythematosus; SLEDAI, SLE Disease Activity Index; WBC, White blood cell Table 2 Demographic and clinical characteristics of

SLE patients experiencing remission before and after treatment.

\begin{tabular}{lll}
\hline Characteristics & Before treatment $(\mathrm{N}=12)$ & After treatment $(\mathrm{N}=12)$ \\
\hline Age, years & $50 \pm 12$ & $50 \pm 12$ \\
Female/male & $10 / 2$ & $10 / 2$ \\
SLEDAI score & $8 \pm 2$ & $2 \pm 2^{* * *}$ \\
Anti-dsDNA, IU/mL & $177.8 \pm 51.32$ & $98.92 \pm 28.55^{* *}$ \\
Serum C3, g/L & $0.72 \pm 0.34$ & $1.25 \pm 0.46^{*}$ \\
Serum C4, g/L & $0.09 \pm 0.07$ & $0.21 \pm 0.10^{*}$
\end{tabular}




\begin{tabular}{lll}
\hline Characteristics & Before treatment $(\mathrm{N}=12)$ & After treatment $(\mathrm{N}=12)$ \\
\hline WBC, $10^{9} / \mathrm{L}$ & $2.98 \pm 1.57$ & $3.53 \pm 0.63$ \\
Platelet, $10^{12} / \mathrm{L}$ & $124.0 \pm 65.9$ & $157.08 \pm 69.94$ \\
Serum Creatinine, $\mu \mathrm{mol} / \mathrm{L}$ & $102.58 \pm 31.16$ & $87.83 \pm 20.39$ \\
Urinary proteins, $\mathrm{g} / 24 \mathrm{~h}$ & $1.73 \pm 1.58$ & $0.20 \pm 0.19^{* *}$ \\
\hline
\end{tabular}

Note: All data are expressed as mean \pm SD. ${ }^{*} \mathrm{p}<0.05,{ }^{* *} \mathrm{p}<0.01,{ }^{* * *} \mathrm{p}<0.001$ vs. the values before treatment

A
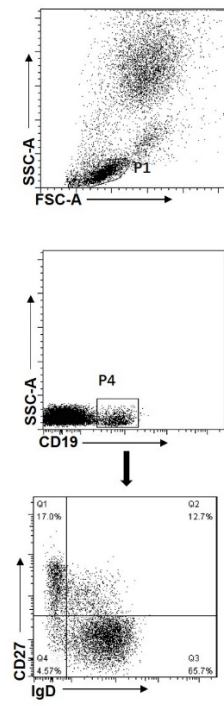

B
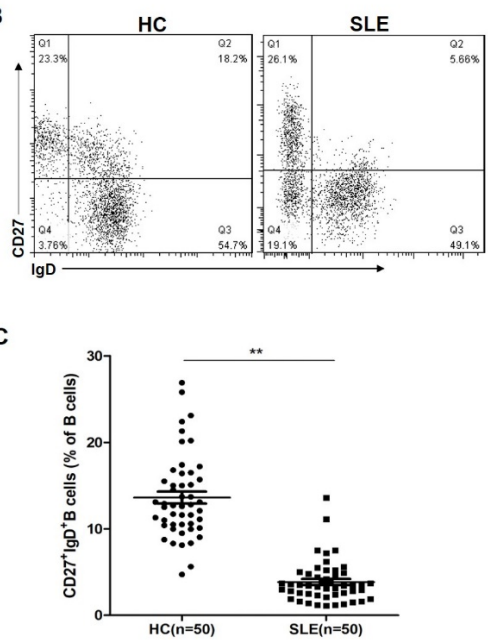

Fig. 1. $\mathrm{CD} 27^{+} \mathrm{IgD}^{+} \mathrm{B}$ cells are decreased in the blood of patients with SLE compared to healthy controls. (A) Gating strategy to identify naïve B cells $\left(\mathrm{CD} 27^{-} \mathrm{IgD}^{+}\right)$, Innate-like B cells $\left(\mathrm{CD} 27^{+} \mathrm{IgD}^{+}\right)$, switched memory B cells $\left(\mathrm{CD} 27^{+} \mathrm{IgD}^{-}\right)$, and double negative B cells $\left(\mathrm{CD} 27^{-} \mathrm{IgD} \mathrm{D}^{-}\right)$in human blood. (B) CD27 ${ }^{+} \mathrm{IgD}^{+} \mathrm{B}$ cells from a representative healthy control (left panel) and an SLE patient (right panel). (C) Percentage of $\mathrm{CD} 27^{+} \operatorname{IgD}^{+} \mathrm{B}$ cells in patients with $\operatorname{SLE}(\mathrm{n}=50)$ and healthy controls $(\mathrm{n}=50)$.

Data are represented as mean +- SD or median +- interquartile range. Data points represent individual subjects. NS $=$ not significant, ${ }^{* *} \mathrm{p}<0.01,{ }^{* * *} \mathrm{p}<0.001$ 


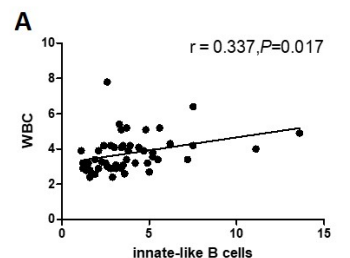

D

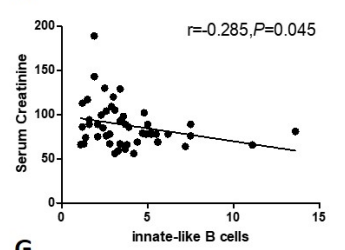

G

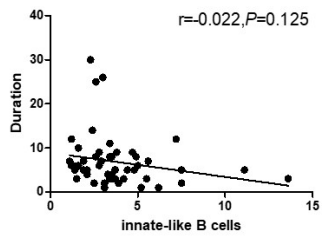

J

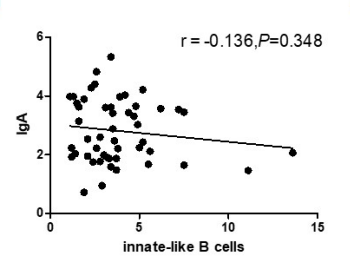

B

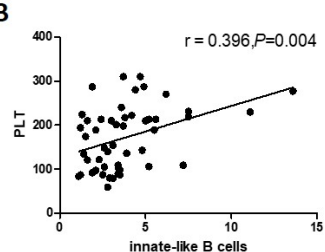

E

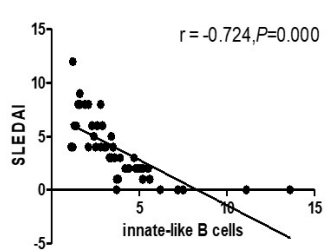

H

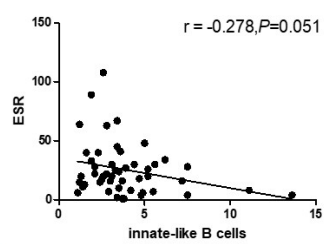

K

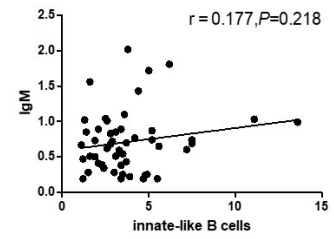

C

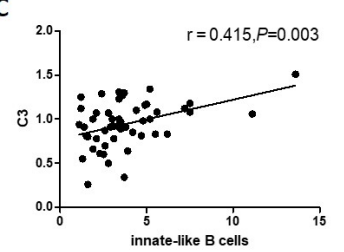

F
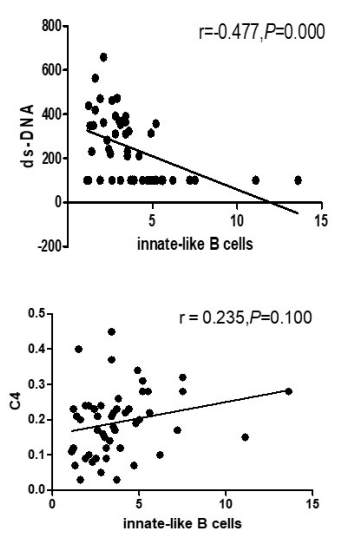

L

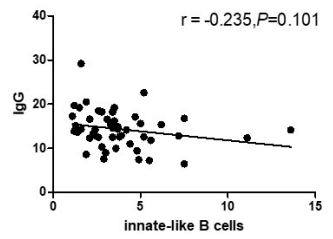

Fig.2 Correlation of $\mathrm{CD}_{2} 7^{+} \operatorname{IgD}{ }^{+} \mathrm{B}$ cells with SLE patient disease manifestations, including the WBC count(A), Platelet count(B), serum C3 (C), Serum Creatinine (D), SLEDAI(E), Anti-dsDNA (F), disease duration $(\mathrm{G}), \operatorname{ESR}(\mathrm{H})$, serum C4(I), $\operatorname{IgA}(\mathrm{J}), \operatorname{IgG}(\mathrm{K})$, and the $\operatorname{IgM}(\mathrm{L})$ was analyzed by the Spearman test $\left({ }^{*} \mathrm{P}\right.$ $\left.<0.05,{ }^{* *} \mathrm{P}<0.01\right)$.

Table 3 Correlation analysis of CD27+ $\operatorname{IgD}+\mathrm{B}$ cells with SLE patient clinical manifestations

\begin{tabular}{lll}
\hline clinical manifestation & $r$ & $P$ \\
\hline WBC & $\mathbf{0 . 3 3 7}$ & $\mathbf{0 . 0 1 7}$ \\
PLT & $\mathbf{0 . 3 9 6}$ & $\mathbf{0 . 0 0 4}^{*}$ \\
C3 & $\mathbf{0 . 4 1 5}$ & $\mathbf{0 . 0 0 3}^{*}$ \\
Serum Creatinine & $\mathbf{0 . 2 8 5}$ & $\mathbf{0 . 0 4 5}$ \\
SLEDAI & $\mathbf{- 0 . 7 2 4}$ & $\mathbf{0 . 0 0 0 * *}$ \\
ds-DNA & $\mathbf{- 0 . 4 7 7}$ & $\mathbf{0 . 0 0 0} * *$ \\
Duration & -0.022 & 0.125 \\
ESR & -0.278 & 0.051 \\
C4 & 0.235 & 0.100 \\
IgA & -0.136 & 0.348 \\
IgM & 0.177 & 0.218 \\
IgG & -0.235 & 0.101 \\
\hline
\end{tabular}

Bold font indicates having statistical significance. ${ }^{*} \mathrm{P}<0.05,{ }^{* *} \mathrm{P}<0.01$. 
A

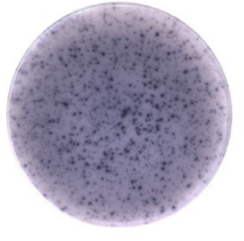

$\mathrm{HC}$

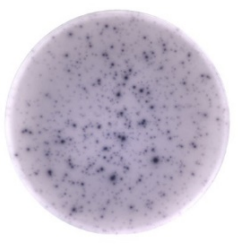

SLE

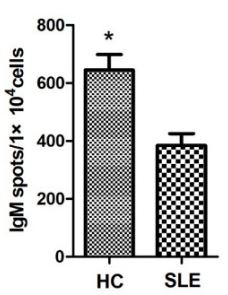

B

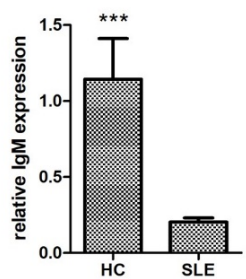

Figure 3 Difference of dampened IgM-producing capacities of $\mathrm{CD} 27^{+} \operatorname{IgD}{ }^{+} \mathrm{B}$ cells between SLE and normal control. Flow cytometry-sorted $\mathrm{CD} 27^{+} \mathrm{IgD}^{+} \mathrm{B}$ cells from four healthy donors and four active SLE patients (SLEDAI >5) were subjected to ELISPOT (A) Real-time PCR (B) analyses of IgM. The representative charts as well as the statistical results were shown (t-test, ${ }^{*} \mathrm{P}<0.05$, ${ }^{* * *} \mathrm{P}<0.001$ ).
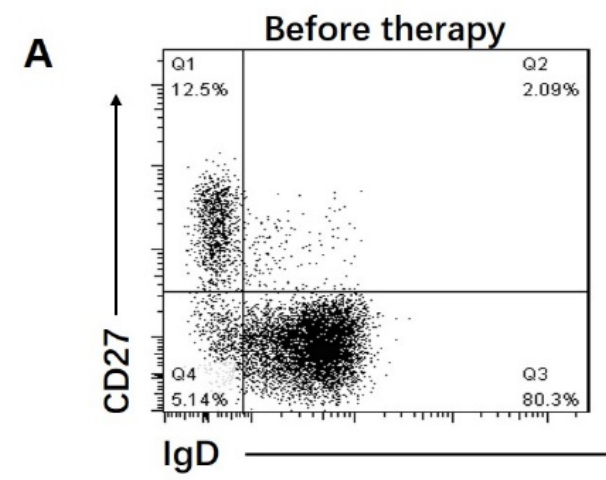

B

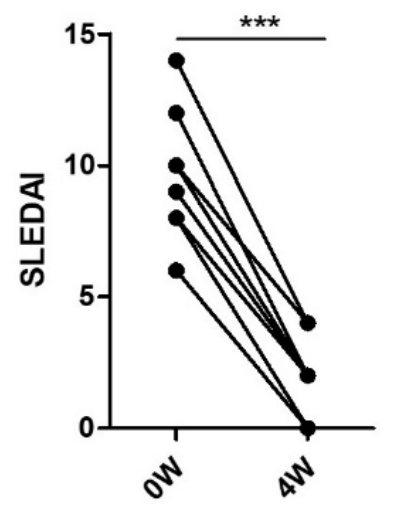

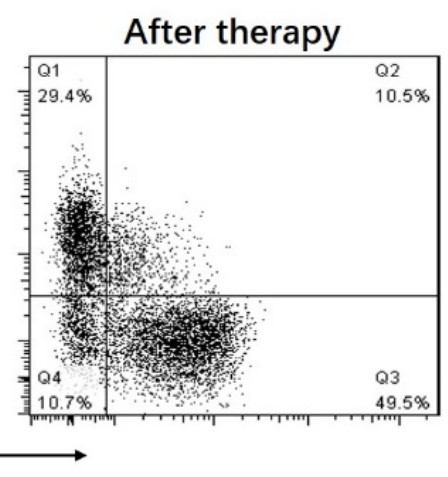

C

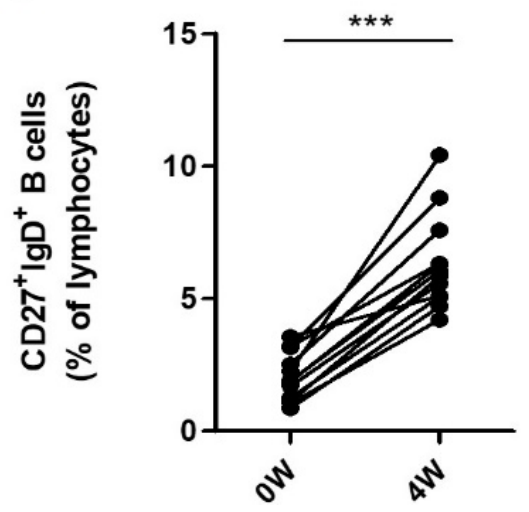

Fig. 4. $\mathrm{CD} 27^{+} \operatorname{IgD}{ }^{+} \mathrm{B}$ cells were increased after treatment in SLE patients. (A) Flow cytometric analysis of the frequencies of $\mathrm{CD}_{2} 7^{+} \mathrm{IgD}^{+} \mathrm{B}$ cells before and after 4 weeks of initiation of treatments. (B) SLEDAI before and after treatment in SLE patients $(\mathrm{n}=12)$. (C) The frequencies of $\mathrm{CD}_{2} 7^{+} \mathrm{IgD}^{+} \mathrm{B}$ cells in SLE patients before and after treatment $(\mathrm{n}=12) .\left({ }^{*} \mathrm{P}<0.05,{ }^{* *} \mathrm{P}<0.01\right)$. 